\title{
Supervision Of Buleleng District Health Office On The Implementation Of Empirical-Traditional Health Service And The Protection of The Community's Right To Health
}

\author{
Pengawasan Dinas Kesehatan Kabupaten Buleleng Bali \\ Terhadap Penyelenggaraan Pelayanan Kesehatan Tradisional Dan \\ Perlindungan Hak Atas Kesehatan Bagi Masyarakat
}

\author{
Karlina Sumiari Tangkas Ni Made; Endang Wahyati Yustina and Daniel Budi Wibowo \\ email: karlina.sumiari@gmail.com \\ Master of Law Science \\ Concentration of Health Law \\ Soegijapranata Catholic University of Semarang
}

\begin{abstract}
Empirical-traditional health service existing in Bali Province, especially in Buleleng District, was growing rapidly. Therefore, it was necessary to monitor the implementation of traditional health services in Buleleng District. The purpose of this study was to know the supervision conducted by Buleleng District Health Office on the implementation of empirical-traditional health service and the protection of the community's right to health. This study used socio-legal approach having an analyticaldescriptive specification and qualitative research design. Data gathering was conducted by having in-depth interviews. The results of the study showed about the legal basis of empirical-traditional health service, implementation of supervision to the Head of Buleleng District's Health Office and The factors influencing the implementation of the supervision. The conclusions that could be drawn was the supervision conducted by the Buleleng District's Health Office was not optimal so that the community's health rights had not been protected. It was suggested that the provincial government, the empiricaltraditional health service providers, and the community as well would push Buleleng District's Health Office to perform better supervision so that it would be able to provide protection for the community's rights to health.
\end{abstract}

Keywords : Supervision, District Office, Traditional Health, Rights

\section{PENDAHULUAN}

\section{A. Latar Belakang}

Kementrian Kesehatan Republik Indonesia berupaya semaksimal mungkin untuk meningkatkan derajat kesehatan masyarakat. Undang-Undang Nomor 36 Tahun 2009 Pasal 4 menyebutkan bahwa "setiap orang berhak atas kesehatan". Pelayanan kesehatan merupakan salah satu upaya pemerintah untuk menunjang terwujudnya hak atas kesehatan tersebut bagi masyarakat. Pelayanan kesehatan tradisional merupakan salah satu dari upaya pelayanan kesehatan masyarakat. Pelayanan kesehatan tradisional diatur dalam Peraturan Pemerintah Nomor 103 Tahun 2014 tentang Pelayanan Kesehatan Tradisional. Pelayanan kesehatan tradisional sudah ada 
sejak dulu dan sampai sekarang terus mengalami perkembangan. Hal tersebut dapat dilihat berdasarkan data Riset Kesehatan Dasar tahun 2013 yakni sejumlah 89.753 dari 294.962 (30,4\%) rumah tangga di Indonesia memanfaatkan pelayanan kesehatan tradisional. Jenis pelayanan kesehatan tradisional yang dimanfaatkan oleh rumah tangga terbanyak adalah keterampilan tanpa alat (77,8\%) dan ramuan (49\%) ${ }^{1}$. Pelayanan kesehatan tradisional dimanfaatkan dengan alasan untuk menjaga kesehatan dan kebugaran, dianggap lebih mampu mengobati penyakit, karena cobacoba, dan karena biayanya lebih murah. ${ }^{2}$ Data di atas menunjukkan bahwa pelayanan kesehatan tradisional memiliki potensi besar untuk berkembang di Indonesia, oleh sebab itu pelayanan kesehatan tradisional perlu mendapatkan perhatian yang serius dari Pemerintah. Pelayanan kesehatan tradisional diselenggarakan guna tercapainya hak atas kesehatan bagi masyarakat. Namun apabila pelayanan kesehatan tradisional tersebut tidak terjamin keamanan, manfaat dan penyelenggaraannya maka hak masyarakat untuk mendapatkan kesehatan pun tidak akan terpenuhi.

Provinsi Bali merupakan bagian dari wilayah Indonesia yang mempunyai adat dan kebudayaan yang sangat kental serta terkenal akan objek wisatanya yang tersebar hampir di seluruh daerah sehingga penyelenggaraan pelayanan kesehatan tradisional menjadi suatu lahan bisnis yang menjanjikan. Fenomena inilah yang mengakibatkan banyaknya tempat penyelenggaraan praktik pelayanan kesehatan tradisional. Berdasarkan hasil rekap data oleh Unit Pelaksana Teknis Jaminan Kesehatan Masyarakat Bali (UPT JKMB), pada tahun 2015, jumlah tenaga penyehat tradisional yang beroperasi di Bali adalah 3281, yang tidak memiliki ijin 3056 sedangkan yang memiliki izin hanya $225^{3}$. Kepala seksi UPT JKMB Dinas Kesehatan Provinsi Bali juga menyampaikan bahwa Kabupaten Buleleng ternyata memiliki penyehat tradisional yang tidak memiliki izin sejumlah $223^{4}$. Berdasarkan hasil pra survey di Kecamatan Seririt Kabupaten Buleleng, masyarakat terbiasa dalam menggunakan pengobatan tradisional seperti terapi herbal, pijat tradisional, pijat patah tulang maupun pijat refleksi. Pengobatan tersebut dicari apabila mereka merasa tidak sembuh melalui pengobatan modern atau medis. Disisi lain masih ada yang menyimpan keraguan terhadap tindakan pelayanan kesehatan tradisional bahwa tindakan pengobatan yang dilakukan melalui pelayanan kesehatan tradisional belum semua berada dalam pengawasan pemerintah, obatnya tidak praktis dan tidak enak, serta kebersihannya juga tidak terjamin sehingga perlindungan terhadap klien pelayanan kesehatan tradisional masih dipertanyakan. Guna menunjang terlaksananya peran pemerintah sebagai penanggung jawab penyelenggaraan pelayanan kesehatan tradisional, maka penyelenggaraan pelayanan kesehatan tradisional wajib diawasi oleh Dinas Kesehatan Kabupaten sehingga hak atas kesehatan masyarakat terpenuhi.

1 Badan Penelitian dan Pengembangan Kesehatan, 2013, Riset Kesehatan Dasar. Jakarta : Kementrian Kesehatan Republik Indonesia, halaman 48

2 Badan Penelitian dan Pengembangan Kesehatan, Ibid, Halaman 49

3 Internet, 19 Juli 2016, Waspada! Ribuan Penyehat Tradisional Tak Kantongi Ijin Praktik, http://www.radarbali.jawapos.com/read/2016/07/19/4184/waspada-ribuan-penyehattradisional-tak-kantongi-izin-praktik/1

${ }^{4}$ Internet, 19 Juli 2016, 3056 Tempat Praktik Balian di Bali Tak Berizin, Tinggal di Pedesaan dan Kaki Gunung, http://www.bali.tribunnews.com/2016/07/19/3056-tempat-praktik-balian-dibali-tak-berizin-tinggal-di-pedesaan-dan-kaki-gunung/page=all 
Pengawasan adalah pengamatan atas pelaksanaan seluruh kegiatan unit organisasi yang diperiksa untuk menjamin agar semua pekerjaan yang sedang dilaksanakan sesuai dengan rencana dan peraturan atau yang disebut kriteria ${ }^{5}$. Adapun pengertian Pemerintah Daerah berdasarkan Undang-Undang Pemerintahan Daerah Pasal 1 Butir 3 "Pemerintah Daerah adalah kepala daerah sebagai unsur penyelenggara Pemerintahan Daerah yang memimpin pelaksanaan urusan pemerintahan yang menjadi kewenangan daerah otonom". Dalam penyelenggaraan pemerintah daerah, kepala daerah dibantu oleh perangkat daerah. Pelayanan kesehatan tradisional empiris adalah pelayanan kesehatan tradisional yang diberikan berdasarkan pengalaman (terutama yang diperoleh dari penemuan, percobaan, pengamatan yang telah dilakukan) atau terbukti secara empiris. Perlindungan hukum adalah memberikan pengayoman terhadap hak asasi manusia (HAM) yang dirugikan oleh orang lain dan perlindungan itu diberikan kepada masyarakat agar dapat menikmati semua hak-hak yang diberikan oleh hukum". ${ }^{6}$

Berdasarkan problematika di atas maka peneliti tertarik untuk meneliti tentang "Pengawasan Dinas Kesehatan Kabupaten Buleleng Bali terhadap Penyelenggaraan Pelayanan Kesehatan Tradisional dan Perlindungan Hak atas Kesehatan bagi Masyarakat". Penelitian ini dibatasi pada pelayanan kesehatan tradisional empiris. Hal ini didukung oleh kuatnya tradisi dan spiritual masyarakat Bali khususnya Buleleng sehingga banyak terdapat pelayanan kesehatan tradisional empiris di masyarakat yang penyelenggarannya sering dikaitkan dengan aspek spiritual. Penelitian dilakukan dengan tujuan melakukan kajian pada pelaksanaan pengawasan Dinas Kesehatan Kabupaten Buleleng terhadap penyelenggaraan pelayanan kesehatan tradisional empiris dan perlindungan hak atas kesehatan bagi masyarakat baik itu dari pengaturan tentang penyelenggaraan pelayanan kesehatan tradisional, pelaksanaan pengawasan serta faktor-faktor yang mempengaruhi pelaksanaan pengawasan. Adapun manfaat dari penelitian ini adalah dapat memberikan masukan kepada Pemerintah khususnya Dinas Kesehatan Kabupaten Buleleng dalam melakukan pengawasan yang lebih baik dan dapat memberikan pemahaman serta pengetahuan tehadap masyarakat dalam mendapatkan pelayanan kesehatan tradisional.

\section{B. Perumusan Masalah}

Menjamurnya pelayanan kesehatan tradisional khususnya pelayanan kesehatan tradisional empiris yang tidak memiliki izin praktik serta tidak terdaftar, mengakibatkan munculnya permasalahan di masyarakat Bali pada umumnya dan masyarakat Buleleng pada khususnya. Apakah pelayanan kesehatan tradisional yang diselenggarakan aman dan bermanfaat ataukah malah akan membuat sakit yang diderita menjadi semakin parah ? Hal inilah yang meresahkan masyarakat oleh karena itu Pemerintah Daerah harus lebih memperhatikan hal tersebut. Berdasarkan Pasal 4 Peraturan Pemerintah Republik Indonesia Nomor 103 Tahun 2014 tentang Pelayanan Kesehatan Tradisional menyebutkan "Pemerintah mempunyai wewenang untuk melakukan pembinaan, pengawasan, dan pengendalian pelayanan kesehatan tradisional" dan untuk itu Menteri dalam melakukan pengawasan melimpahkan wewenang kepada kepala Dinas Kesehatan Provinsi dan kepala Dinas Kabupaten/Kota sesuai Pasal 78 Ayat (2). Untuk

${ }^{5}$ Sumardjo. 2001. Menyikapi Fungsi Pengawasan dan Temuan. Jakarta : BP Panca Usaha, halaman 3

${ }^{6}$ Satjipto Rahardjo, 2000, IImu Hukum, Bandung : Citra Aditya Bakti., halaman 53 
itu penyelenggaraan pelayanan kesehatan tradisional wajib diawasi oleh Dinas Kesehatan Kabupaten sehingga hak atas kesehatan masyarakat terpenuhi. Dengan demikian peneliti tertarik untuk melakukan untuk melakukan penelitian terkait pengawasan Dinas Kesehatan Kabupaten Buleleng terhadap Penyelenggaraan Pelayanan Kesehatan Tradisional dan Perlindungan Hak Atas Kesehatan Bagi Masyarakat. Adapun rumusan masalah yang akan dikaji antara lain bagaimana pengaturan penyelenggaraan pelayanan kesehatan tradisional empiris, bagaimana pelaksanaan pengawasan Dinas Kesehatan Kabupaten Buleleng terhadap penyelenggaraan pelayanan kesehatan tradisional empiris dan perlindungan ha katas kesehatan bagi masyarakat serta apa faktor-faktor yang mempengaruhi pelaksanaan pengawasan.

\section{Metode Penelitian}

Penelitian dilakukan di lingkungan Dinas Kesehatan Kabupaten Buleleng, penyelenggara pelayanan kesehatan tradisional empiris dan klien dari pelayanan kesehatan tradisional empiris. Penelitian ini menggunakan metode pendekatan yuridis sosiologis dengan spesifikasi penelitian deskriptif analitik. Adapun desain penelitian yang digunakan adalah desain penelitian kualitatif. Penelitian ini memiliki tiga unsur penelitian yang dijabarkan ke dalam tabel definisi operasional.

Tabel 1.1 Definisi Operasional

\begin{tabular}{|c|c|c|}
\hline No & Unsur & Definisi Operasional \\
\hline a) & $\begin{array}{l}\text { Pengawasan Dinas } \\
\text { Kesehatan } \\
\text { Kabupaten } \\
\text { Buleleng Bali }\end{array}$ & $\begin{array}{l}\text { Menganalisis bagaimana pengawasan yang dilakukan oleh Dinas } \\
\text { Kesehatan Kabupaten Buleleng Bali dalam mengawasi atau memeriksa } \\
\text { pelaksanaan seluruh kegiatan unit organisasi untuk menjamin agar semua } \\
\text { pekerjaan yang sedang dilaksanakan sesuai dengan rencana dan } \\
\text { peraturan atau yang disebut kriteria penyelenggaraan pelayanan } \\
\text { kesehatan tradisional. Peraturan penyelenggaraan pelayanan kesehatan } \\
\text { tradisional merupakan pedoman yang digunakan untuk mengatur } \\
\text { penyelenggaraan pelayanan kesehatan tradisional. Adapun cara } \\
\text { pengawasan yang dilakukan: } \\
\text { (1) Ditinjau dari badan/organ yang melakukan pengawasan } \\
\text { (2) Ditinjau dari waktu dilaksanakannya } \\
\text { (3) Ditinjau dari segi hukum }\end{array}$ \\
\hline b) & $\begin{array}{l}\text { Penyelenggaraan } \\
\text { Pelayanan } \\
\text { kesehatan } \\
\text { tradisional empiris }\end{array}$ & $\begin{array}{l}\text { Suatu sistem penerapan kesehatan tradisional yang manfaat dan } \\
\text { keamanannya terbukti secara empiris, dan wajib untuk diawasi. Peraturan } \\
\text { penyelenggaraan pelayanan kesehatan tradisional empiris yang wajib } \\
\text { untuk diawasi meliputi: } \\
\text { (1) Fasilitas kesehatan (sarana prasarana) } \\
\text { (2) Metode yang digunakan, alat dan bahan } \\
\text { (3) Pelaksana Pelayanan Kesehatan Tradisional Empiris (Penyehat } \\
\text { tradisional) }\end{array}$ \\
\hline c) & $\begin{array}{l}\text { Perlindungan hak } \\
\text { atas kesehatan } \\
\text { bagi masyarakat }\end{array}$ & $\begin{array}{l}\text { Menganalisis bagaimana perlindungan hak atas kesehatan bagi } \\
\text { masyarakat sebagai pengguna pelayanan kesehatan tradisional, meliputi : } \\
\text { (1) Dilakukannya Pengawasan } \\
\text { (2) Pemberian sanksi }\end{array}$ \\
\hline
\end{tabular}


Penelitian ini menggunakan data primer dan data sekunder dimana pengumpulan data dilakukan melalui studi lapangan dengan wawancara dan studi kepustakaan. Adapun dalam pengambilan sampel menggunakan teknik purposive sampling. Penelitian ini mengelompokkan sampel penyelenggara dan klien pelayanan kesehatan tradisional berdasarkan metode yang digunakan yakni terhadap 16 jenis metode dimana peneliti mengambil 8 jenis metode yang digunakan sehingga sampel menjadi representative. Adapun kriteria pemilihan objek penelitian dilihat dari jenis pelayanan kesehatan tradisional yang penggunaan pengobatannya paling diminati oleh masyarakat Kabupaten Buleleng. Analisis data yang digunakan adalah analisis data kualitatif.

\section{PEMBAHASAN}

\section{Pengaturan Penyelenggaraan Pelayanan Kesehatan Tradisional Empiris}

\section{a. Dasar Hukum Pengaturan Penyelenggaraan Pelayanan Kesehatan Tradisional Empiris}

Dasar hukum merupakan ketentuan dalam peraturan perundang-undangan yang menjadi landasan bagi setiap penyelenggaraan atau tindakan hukum oleh subjek hukum. Adapun dasar hukum pengaturan penyelenggaraan pelayanan kesehatan tradisional antara lain :

1) Undang-Undang Dasar Negara Republik Indonesia 1945 (UUD 1945)

UUD 1945 dengan jelas mengatur adanya hak sehat bagi masyarakat dimana tujuannya adalah untuk menjamin setiap orang agar mendapatkan hak untuk hidup sehat. Hak hidup sehat itu dapat dipenuhi melalui pengembangan pelayanan kesehatan tradisional yang merupakan bagian dari pengembangan budaya.

2) Undang-Undang Republik Indonesia Nomor 8 Tahun 1999 Tentang Perlindungan Konsumen

Undang-Undang Nomor 8 Tahun 1999 pada intinya mengatur tentang perlindungan hukum bagi konsumen, dalam ini merupakan klien dari pelayanan kesehatan tradisonal baik itu pengguna jasa ramuan dan obat tradisional.

3) Undang-Undang Republik Indonesia Nomor 32 Tahun 2002 Tentang Penyiaran Undang-Undang ini pada intinya mengatur tentang informasi terkait iklan pelayanan kesehatan yang dapat disiarkan.

4) Undang-Undang Republik Indonesia Nomor 10 Tahun 2009 tentang Kepariwisataan

Undang-Undang ini pada intinya mengatur terkait tentang usaha pariwisata dimana SPA merupakan salah satu dari usaha wisata, dimana di satu sisi SPA merupakan salah satu upaya daro Pelayanan Kesehatan Tradisional.

5) Undang-Undang Republik Indonesia Nomor 36 Tahun 2009 Tentang Kesehatan Inti pengaturan dari Undang-Undang Nomor 36 Tahun 2009 Tentang kesehatan adalah hak hidup sehat bagi semua orang dan untuk itu Pemerintah bertanggung jawab dalam memenuhi hak sehat tersebut melalui pelayanan kesehatan yang diselenggarakan. Selain itu UU Kesehatan ini juga mengatur terkait tentang fasilitas pelayanan kesehatan, upaya pelayanan kesehatan, pelayanan kesehatan tradisional, serta pemberdayaan masyarakat terkait penyelenggaraan pelayanan kesehatan tradisional. UU Kesehatan juga mengatur bagaimana pelaksanaan tanggung jawab pemerintah terhadap penyelenggaraan pelayanan kesehatan 
mulai dari pembinaan, pengawasan, dan tindak lanjut terkait sanksi pidana dan ganti rugi sebagai bentuk perlindungan hak sehat bagi masyarakat.

6) Undang-Undang Nomor 23 Tahun 2014 Tentang Pemerintahan Daerah

Undang-Undang Pemerintahan Daerah ini pada intinya mengatur mengenai urusan pemerintahan wajib, serta penyelenggaraan Pemerintahan Daerah yakni Dinas dimana Dinas merupakan perangkat kerja daerah dalam melaksanakan kewenangan daerah. Terkait urusan pemerintahan wajib dalam hal kesehatan maka dinas kesehatan yang memiliki wewenang dan bertanggung jawab terhadap pelaksanaannya termasuk dalam hal pengawasan oleh Dinas Kesehatan terhadap penyelenggaraan pelayanan kesehatan tradisional.

7) Peraturan Pemerintah Nomor 103 Tahun 2014 tentang Pelayanan Kesehatan Tradisonal

Inti pengaturan Peraturan Pemerintah Nomor 103 Tahun 2014 adalah mengatur tentang jenis pelayanan kesehatan tradisional, metode dalam pelayanan kesehatan, penyehat tradisional, obat tradisional, fasilitas pelayanan kesehatan, hak dan kewajiban klien serta penyelenggara pelayanan kesehatan tradisional empiris, pembinaan, pengawasan, serta sanksi yang diberikan jika ada temuan pelanggaran.

8) Peraturan Presiden Nomor 72 Tahun 2012 Tentang Sistem Kesehatan Nasional Peraturan Presiden ini merupakan instrumen untuk melakukan pembangunan di bidang kesehatan dimana terdapat sub sistem terkait upaya kesehatan yang diselenggaraakan melalui pelayanan kesehatan tradisional.

b. Bentuk Pengaturan Penyelenggaraan Pelayanan Kesehatan Tradisional Empiris Dalam penyelenggaraan pelayanan kesehatan tradisional empiris maka secara umum diatur dalam Peraturan Menteri Kesehatan (PMK) Nomor 61 Tahun 2016 Tentang Pelayanan Kesehatan Tradisional Empiris. PMK ini merupakan aturan pelaksana dari PP Nomor 103 Tahun 2014 Tentang Pelayanan Kesehatan Tradisional. Hal-hal pokok yang diatur mengenai : penyehat tradisional; metode pelayanan; obat tradisional atau ramuan yang digunakan; serta fasilitas pelayanan kesehatan. Selebihnya diatur pula mengenai alat dan teknologi; iklan; penapisan/skrining; pencatatan dan pelaporan; pembinaan; pengawasan; dan sanksi.

1) Penyehat tradisional

Diatur terkait dengan asal pengetahuan dan keterampilan yakni pada Pasal 3; STPT (Surat Terdaftar Penyehat Tradisional) yang diatur pada Pasal 4, 5, 7, 8 dan Pasal 9 dimana penyehat tradiisonal wajib memiliki STPT dan sertifikat kompetensi. Adapun kode etik penyehat tradisional yang diatur pada Pasal 18.

2) Metode Pelayanan

Diatur terkait dengan Persyaratan kompetensi pelayanan kesehatan tradisional empiris pada Pasal 10. Konsep dan ciri khas pelayanan kesehatan tradisional empiris yang diatur pada Pasal 11, 12 dan Pasal 17, dimana secara khusus diatur pula pada Peraturan Menteri Kesehatan Nomor 8 Tahun 2014 Tentang Pelayanan Kesehatan SPA Pasal 3. Jika dilihat berdasarkan dengan Peraturan Menteri Pariwisata Nomor 18 Tahun 2016 tentang Pendaftaran Usaha Pariwisata Pasal 6 Huruf m maka SPA memang termasuk ke dalam salah satu jenis usaha wisata. Adapun cara pelayanan kesehatan tradisional empiris diatur pada Pasal 13, Pasal 14 terkait dengan keterampilan, Pasal 15 terait dengan 
ramuan, dan Pasal 16 terkait dengan metode yang menggunakan perpaduan antara keterampilan dan ramuan. Berdasarkan Peraturan Menteri Kesehatan Nomor 8 Tahun 2014 Tentang Pelayanan Kesehatan SPA, SPA merupakan salah satu dari pelayanan kesehatan tradisional dimana SPA memanfaatkan dua teknik pengobatan yaitu secara keterampilan dan juga ramuan. SPA memanfaatkan keterampilan akupresur dan digabungkan dengan ramuan herbal, aromaterapi ataupun terapi hidro.

3) Fasilitas Pelayanan Kesehatan

Tempat pelayanan kesehatan tradisional empiris diatur pada Pasal 19 dimana pelayanan kesehatan tradisional empiris dilakukan oleh penyehat tradisional di panti sehat. Adapun syarat dari panti sehat akan dijelaskan pada Pasal 20, 24, 25, dan Pasal 26. Syarat teknis sarana dan prasarana pelayanan kesehatan SPA juga diatur dalam PAsal 12 dan Pasal 15 PMK Pelayanan Kesehatan SPA. Terkait dengan izin teknis penyelenggaraan tempat pelayanan kesehatan tradisional empiris ini diatur pada Pasal 21, 22 dan Pasal 23, serta diatur pula pada Pasal 8, 9, 10, 11 dan Pasal 13 PMK Pelayanan Kesehatan SPA. Peraturan Menteri Pariwisata Nomor 18 Tahun 2016 Tentang Pendaftaran Usaha Pariwisata Pasal 15 juga mengatur terkait dengan pengurusan Tanda Daftar Usaha Pariwisata.

4) Alat dan teknologi

Alat dan teknologi yang boleh digunakan diatu pada Pasal 27 sedangkan alat dan teknologi yang tidak boleh digunakan diatur pada Pasal 28, 29 dan Pasal 30. Alat dan teknologi tersebut juga harus terjamin keamanannya dan ini diatur pada Pasal 31.

5) Bahan Obat Tradisional

Penggunaan obat tradisional dan ramuan diatur pada Pasal 32, 35 dan 36. Secara khusus diatur pula pada Peraturan Menteri Kesehatan Republik Indonesia Nomor 6 tahun 2016 tentang Formularium Obat Herbal Asli Indonesia serta Peraturan Menteri Kesehatan Republik Indonesia Nomor 9 tahun 2016 tentang Upaya Pengembangan Kesehatan Tradisional Melalui Asuhan Mandiri Pemanfaatan Taman Obat Keluarga Dan Keterampilan dimana Pasal 70 menyebutkan jika diperlukan upaya mendorong masyarakat agar berperan aktif serta dapat melakukan perawatan kesehatan secara mandiri dan benar dengan dengan memanfaatkan Taman Obat Keluarga (TOGA) dan Keterampilan sebagai bagian dari upaya kesehatan tradisional. Terkait dengan syarat ruangan pembuatan obat tradisional dan ramuan racikan sendiri diatur pada Pasal 34.

6) Iklan

Iklan diatur pada Pasal 37 dan secara khusus diatur pula pada Peraturan Menteri Kesehatan Nomor 1787 tahun 2010 Tentang Iklan dan Publikasi Pasal 5 Huruf $f$. Peraturan Komisi Penyiaran Indonesia (KPI) Nomor 02/P/KPI/03/2012 tentang Standar Program Siaran Pasal 11 menyebutkan jika program siaran yang berisi tentang kesehatan masyarakat dilarang menampilkan penyedia jasa pelayanan kesehatan masyarakat yang tidak memiliki izin dari lembaga yang berwenang

7) Penapisan/skrining

Pelaksanaan penapisan tertuang pada Pasal 6 dimana Dinas Kesehatan Kabupaten/Kota dapat melibatkan unit yang salah satu fungsinya melakukan penapisan atas cara/metode/teknik/bahan/alat berteknologi pada pelayanan kesehatan tradisional yang digunakan seperti Sentra P3T yang memang 
berfungsi dalam pengembangan dan penapisan pengobatan tradisional. Adapun kegunaan SP3T diatur pada Pasal 39 dan secara khusus juga tertuang dalam Peraturan Menteri Kesehatan Nomor 90 Tahun 2013 tentang Sentra Pengembangan dan Penerapan Pengobatan Tradisional (SP3T).

8) Pencatatan dan pelaporan

Pencatatan dan pelaporan diatur pada Pasal 38 serta diatur pula pada PMK Pelayanan Kesehatan SPA Pasal 15 Huruf g. Jadi tampak jelas jika penyelenggara pelayanan kesehatan tradisional empiris wajib untuk melakukan pencatatan dan pelaporan.

9) Pembinaan

Pembinaan diatur pada 40 dan Pasal 41. Selain itu PMK Pelayanan Kesehatan SPA juga mengatur mengenai pembinaan terhadap penyelenggara pelayanan kesehatan SPA dimana tercantum pada Pasal 17.

10)Pengawasan

Aspek pengawasan diatur pada Pasal 40. Dalam melaksanakan pengawasan, Dinas Kesehatan Kabupaten dapat mengangkat tenaga pengawas dimana hal ini tercantum pada Pasal 42 Ayat (1). Tugas dari tenaga pengawas ini tertera pada Pasal 42 Ayat (2) dan Pasal 43. Selain itu pelaksanaan pengawasan tertuang pada Pasal 42 ayat (3) dimana Pemerintah melakukan pengawasan secara berjenjang dengan melibatkan institusi terkait, asosiasi penyehat tradisional dan masyarakat sehingga hak sehat dapat terpenuhi. Adapun instrumen pengawasan tertuang pada Ayat (4). PMK Pelayanan Kesehatan SPA juga mengatur mengenai pembinaan dan pengawasan terhadap penyelenggara pelayanan kesehatan SPA seperti yang tertera pada Pasal 17 Ayat (1). SPA juga diawasi oleh Kementrian Pariwisata dimana mengingat jika SPA termasuk ke dalam usaha wisata. Jadi, Dinas Pariwisata terlibat dalam melakukan pembinaan dan pengawasan terhadap usaha wisata yang ada. Pasal 33 PMP Pendaftaran Usaha Pariwisata tampak jika kegiatan dilakukan dengan melakukan pemeriksaan berkala ke lapangan untuk memastikan kesesuaian kegiatan usaha dengan TDUP yang dimiliki. Selain itu terkait dengan pengawasan juga diatur dalam UndangUndang nomor 8 Tahun 2002 tentang Perlindungan Konsumen, dimana dalam hal pengawasan juga melibatkan Lembaga Perlindungan Konsumen Swadaya Masyarakat dan juga melibatkan masyarakat itu sendiri sebagai konsumen terhadap jasa pelayanan kesehatan tradisional.

11) Sanksi

Penerapan sanksi tertuang pada lampiran PMK Pelayanan Kesehatan Tradisional Empiris. Adapun dalam PMK Pelayanan Kesehatan SPA, sanksi administrasi yang dapat diberikan berupa teguran lisan, teguran tertulis dan/atau pencabutan izin. Hal tersebut tertuang pada Pasal 17 Ayat (2) dan (3).

\section{c. Tujuan Pengaturan}

Pengaturan penyelenggaraan pelayanan kesehatan tradisional empiris memiliki tujuan sebagai berikut :

1) Untuk melaksanakan amanat perundang-undangan

Dalam rangka melaksanakan amanat perundang-undangan maka diperlukan atuar pelaksana dari ketentuan peraturan perundang-undangan yang ada di atasnya. 
2) Sebagai bentuk pengawasan preventif yang dilakukan oleh Pemerintah Daerah Dalam penyelenggaraan pelayanan kesehatan tradisional sudah diketahui sebelumnya jika para penyehat tradisional harus memiliki STPT, izin usaha bagi panti sehat berkelompok, izin edar bagi alat dan tekonologi yang digunakan. Jadi sebelum penyehat tradisional tersebut melaksanakan pelayanan kesehatan tradisional empiris maka sudah diawasi terlebih dahulu terkait dengan legalitas penyelenggara, bahan, metode, obat serta fasilitas yang digunakan dimana hal tersebut akan dinilai secara teknis sebelum kegiatan pelayanan kesehatan tradisional berjalan. Untuk itu dapat dikatakan jika adanya aturan terkait penyelenggaraan pelayanan kesehatan tradisional dapat dikatakan sebagai salah satu bentuk pengawasan preventif yang dilakukan sebelum kegiatan tersebut berlangsung.

3) Sebagai bentuk perlindungan hak sehat dengan memberikan jaminan kepada masyarakat guna mendapatkan pelayanan yang bermutu

Hak masyarakat untuk sehat merupakan kepentingan dari masyarakat tersebut dan untuk itu sudah merupakan kewajiban negara dalam hal ini Pemerintah untuk mewujudkan hak tersebut. Untuk itu diperlukanlah perlindungan hak oleh negara. Perlindungan hak oleh negara kepada warganya bisa berbentuk perlindungan hukum. Perlindungan hukum ada dua bagian yaitu perlindungan hukum preventif (perlindungan diberikan pemerintah dengan tujuan untuk mencegah sebelum terjadi pelanggaran) dan perlindungan represif (perlindungan akhir berupa sanksi). Pelaksanaan perlindungan hukum preventif yakni mencegah terjadinya pelanggaran maka Pemerintah membuat peraturan perundang-undangan dan diterbitkanlah Undang-Undang mengenai Kesehatan serta Peraturan Pemerintah terkait Pelayanan Kesehatan Tradisional serta Peraturan Menteri terkait Pelayanan Kesehatan Tradisional Empiris.

4) Sebagai pedoman dalam menyelenggarakan pelayanan kesehatan tradisional empiris

Adanya pedoman yang digunakan dalam mengatur penyelenggaraan pelayanan kesehatan tradisional empiris ditujukan agar masyarakat hidup tertib dan teratur. Jika tidak terdapat peraturan maka manusia bisa bertindak sewenang-wenang, tanpa kendali dan sulit diatur. Untuk itu diperlukanlah aturan yang dapat mengatur penyelenggaraan pelayanan kesehatan tradisional empiris sehingga pelaksanaannya dapat berjalan dengan tertib, manfaat terjamin serta mencegah terjadinya pelanggaran yang dapat merugikan masyarakat.

2. Pelaksanaan Pengawasan Dinas Kesehatan Kabupaten Buleleng Terhadap Penyelenggaraan Pelayanan Kesehatan Tradisional Empiris dan Perlindungan Hak Atas Kesehatan Bagi Masyarakat

\section{a. Lembaga yang melakukan pengawasan}

Berdasarkan hasil penelitian maka lembaga yang sepenuhnya melakukan pengawasan terhadap penyelenggaraan pelayanan kesehatan tradisional empiris di tingkat kabupaten khususnya dalam lingkup Kabupaten Buleleng adalah Dinas Kesehatan Kabupaten Buleleng. Hal tersebut sesuai dengan Undang-Undang Nomor 23 Tahun 2014 Tentang Pemerintahan Daerah Pasal 209 Ayat (2). Dalam 
melakukan tugasnya sebagai pengawas maka Dinas Kesehatan Kabupaten Buleleng melakukan koordinasi dengan instansi atau lembaga tertentu sehingga pelaksanaan pengawasan dapat berjalan dengan baik diantaranya :

1) Dinas Kesehatan Provinsi Bali

Dinas Kesehatan Kabupaten akan melakukan koordinasi yakni dengan melakukan pelaporan kepada Dinas Kesehatan Provinsi terkait penyelenggaraan pelayanan kesehatan tradisional empiris yang ada di kabupaten.

2) Dinas Pariwisata Kabupaten

Dinas pariwisata kabupaten merupakan perangkat daerah tingkat kabupaten yang mengurusi urusan usaha pariwisata. Jika dilihat dari tingkat kepentingannya maka jelas bahwa antara dinas kesehatan memiliki kepentingan yang berbeda dengan dinas pariwisata. Namun dalam hal pelayanan kesehatan tradisional empiris yang merupakan kegiatan pelayanan kesehatan yang memang berasal dari pengembangan budaya terkait prilaku kesehatan, maka hal tersebut dapat dikembangkan menjadi aset wisata pariwisata Buleleng, Bali. Sementara dinas kesehatan memiliki tugas untuk pengawasan dan pengadaan kegiatan untuk melindungi masyarakat. Jadi ada dua kepentingan yang berbeda dan hal ini mestinya dikoordinasikan. Sehingga tetap dapat menyelenggarakan pelayanan kesehatan tradisional menjadi objek wisata bahkan menjadi yang lebih menarik tetapi tidak meninggalkan kepentingan perlindungan masyarakat. Jadi dalam hal ini maka dinas kesehatan dapat berbagi tugas dengan dinas pariwisata dalam hal pengawasan terhadap penyelenggaraan pelayanan kesehatan tradisional seperti SPA. SPA merupakan salah satu pelayanan kesehatan tradisional empiris dimana selain termasuk ke dalam pelayanan kesehatan tradisional, SPA juga termasuk dalam salah satu usaha pariwisata sesuai dengan Pasal 14 Undang-Undang Nomor 10 Tahun 2009 tentang Kepariwisataan.

Berdasarkan Peraturan Menteri Pariwisata RI Nomor 18 Tahun 2016 Tentang Pendaftaran Usaha Pariwisata Pasal 6 menyebutkan jika SPA merupakan salah satu usaha pariwisata. Jadi dalam kegiatan pengawasan terhadap usaha SPA tersebut maka Dinas pariwisata melakukan pembinaan dan pengawasan terhadap usaha wisata. Adapun kegiatan pengawasan yang dilakukan dapat berupa pemeriksaan sewaktu-waktu ke lapangan untuk memastikan kesesuaian kegiatan usaha dengan TDUP dan hal ini tercantum dalam Pasal 33 PMP Pendaftaran Usaha Pariwisata. Selain itu Petunjuk Teknis Tata Cara Pendaftaran Usaha Pariwisata Tahun 2016 Kementrian Pariwisata Republik Indonesia, menyebutkan jika pengawasan terhadap jasa usaha pariwisata dilaksanakan oleh SKPD yang membidangi pariwisata dalam rangka memantau pelaksanaan usaha sesuai dengan TDUP baik langsung melalui tinjauan terhadap kantor/lokasi usaha pariwisata maupun tidak langsung melalui surat menyurat/komunikasi. Pemeriksaan dilakukan sewaktu-waktu jika dipandang perlu untuk memastikan kesesuaian kegiatan usaha dengan daftar usaha pariwisata seperti alamat kantor, kegiatan usaha sesuai dengan pendaftaran usahanya, kapasitas/fasilitas yang dimiliki apakah sesuai dengan yang diberitahukan serta pemeriksaan terhadap perubahan-perubahan yang terjadi seperti perubahan luas kantor, penambahan fasilitas, perubahan waktu dan durasi operasi dan lain-lain. 
3) Lembaga Penyiaran

Penyehat tradisonal dilarang melakukan publikasi ataupun iklan terhadap metode pelayanan kesehatan tradisional ataupun ramuan yang digunakan. Untuk itu Dinas Kesehatan Kabupaten bekerja sama dan melakukan koordinasi dengan lembaga penyiaran dan informasi terkait iklan dan publikasi yang disiarkan. Dalam Undang-Undang Nomor 32 Tahun 2002 Tentang Penyiaran terutama Pasal 5 Huruf I menyebutkan bahwa penyiaran diarahkan untuk memberi informasi yang benar, seimbang, dan bertanggung jawab. Aturan terkait siaran kesehatan pada lembaga penyiaran juga telah dituangkan dalam Peraturan Komisi Penyiaran Indonesia (KPI) Nomor 02/P/KPI/03/2012 tentang Standar Program Siaran. Pada Pasal 11 Ayat (3) disebutkan jika program siaran yang berisi tentang kesehatan masyarakat dilarang menampilkan penyedia jasa pelayanan kesehatan masyarakat yang tidak memiliki izin dari lembaga berwenang. Berdasarkan bunyi pasal tersebut maka lembaga penyiaran berhak menanyakan izin dari jasa pelayanan kesehatan yang ingin berpromosi. Untuk itu lembaga penyiaran difungsikan untuk memilah dan menyaring penyiaran iklan terkait pelayanan kesehatan tradisional yang dilakukan dimana lembaga penyiaran diharapkan untuk tidak menyiarkan iklan terkait metode serta obat tradsional yang digunakan oleh penyehat tradisional.

4) Asosiasi Penyehat Tradisional

Asosiasi penyehat tradisional difungsikan dalam pengawasan terkait kode etik, identifikasi anggotanya baik dalam hal jumlah dan lokasi tempat praktik pelayanan kesehatan tradisional. Asosiasi penyehat tradisional dapat melakukan pelaporan kepada Dinas Kesehatan mengenai keanggotaan dari asosiasi pelayanan kesehatan tradisional. Selain itu dapat pula dinas kesehatan bekerjasama dengan asosiasi penyehat tradisional dalam pengadaan pelatihan guna meningkatkan keterampilan dan pengetahuan para anggotanya.

\section{b. Bentuk pengawasan}

1) Ditinjau dari kedudukan badan/organ yang melaksanakan pengawasan

Dalam melakukan pengawasan terhadap pelayanan kesehatan tradisional empiris Dinas Kesehatan memiliki perangkat atau seksi terkait dengan pelaksanaan pelayanan kesehatan tradisional. Pelaksanaan pengawasan tersebut dilakukan oleh Seksi Pelayanan Kesehatan Tradisional. Kepala Seksi Pelayanan Kesehatan tradisional memiliki tanggung ja1wab atas kegiatan pelaksanaan pelayanan kesehatan tradisional yang ada di Kabupaten Buleleng.

2) Ditinjau dari segi waktu dilaksanakannya

Dinas Kesehatan Kabupaten Buleleng melakukan pengawasan preventif dimana sebelum kegiatan pelayanan kesehatan tradisional dilaksanakan, berdasarkan amanat yang telah ditetapkan oleh Menteri Kesehatan terkait dengan penggunaan alat kesehatan, obat tradisional/herbal, dan metode pelayanan yang digunakan, maka, Dinas Kesehatan Kabupaten melakukan penilaian terhadap izin edar dari alat dan teknologi yang digunakan dan terhadap obat tradisional/herbal yang digunakan. Dinas Kesehatan memantau juga terkait keberlakuan izin edar yang terdapat dalam alat maupun obat tersebut serta syarat yang harus dipenuhi. Jadi dalam melakukan pengawasan preventif, maka 
Dinas Kesehatan Kabupaten Buleleng melakukan penilaian teknis terlebihdahulu sebelum memberikan rekomendasi.

Adapun pengawasan represif yang dilakukan oleh Dinas Kesehatan Kabupaten Buleleng, setelah adanya PMK Pelayanan Kesehatan Tradisional Empiris Nomor 61 Tahun 2016, maka Dinas Kesehatan Kabupaten Buleleng wajib untuk melakukan pengawasan dan pembinaan terkait dengan penyelenggaraan pelayanan kesehatan tradisional yang ada di wilayah Kabupaten Buleleng.

3) Ditinjau dari segi hukum

Dinas Kesehatan merupakan pihak yang membantu proses penegakan hukum di pengadilan. Apabila dalam melakukan pengawasan ditemukan temuan yang melanggar hukum maka Dinas Kesehatan akan melaporkan kepada pihak berwenang seperti kepolisian atau dalam hal ini adalah penyidik. Jadi dalam hal ini Dinas Kesehatan Kabupaten Buleleng melakukan kerjasama lintas sektor dimana hasil akhirnya akan diselesaikan di Penagdilan Negeri.

\section{c. Mekanisme pengawasan}

Pengawasan dilakukan untuk melihat kesesuaian antara pengaturan dengan keadaan atau kondisi lapangan. Ada tiga tahapan mekanisme pengawasan yang dilakukan oleh Dinas Kesehatan Kabupaten Buleleng antara lain :

1) Membentuk tim pengawas

Seksi pelayanan kesehatan tradisional Dinas Kesehatan Kabupaten Buleleng terdiri dari kepala seksi serta dua orang anggota, dimana dalam melakukan pengawasan melibatkan kerjasama lintar program yang ada di Dinas Kesehatan dan lintas sektor sesuai dengan Keputusan Bupati Buleleng Nomor 440/129/HK/2017 tentang Tim Pembina dan Penilai Lomba Taman Obat Keluarga Dan Tim Pembina Dan Pengawasan Pelayanan Kesehatan Tradisional Tingkat Kabupaten Buleleng Tahun 2017. Adapun dalam kegiatan lintas program melibatkan program kesehatan lingkungan, farmasi, dan pelayanan rujukan sedangkan lintas sektor melibatkan Kejaksaan Negeri, Reserse Kepolisian Resort Buleleng, dan Kesatuan Polisi Pamong Praja. Selain itu Dinas Kesehatan Kabupaten Buleleng memiliki pemegang program kesehatan tradisional di masing-masing puskesmas yang sekaligus merangkap sebagai tenaga pengawas.

2) Melakukan pemeriksaan

Dalam melakukan pemeriksaan, Dinas Kesehatan Kabupaten Buleleng melakukan tiga tahap, antara lain :

a) Penilaian administrasi dan teknis sebelum memberikan rekomendasi

Rekomendasi merupakan syarat untuk mendapatkan STPT. Rekomendasi dikeluarkan oleh Dinas Kesehatan Kabupaten Buleleng setelah dilakukan penilaian teknis terhadap penyehat tradisional (legalitas dan kualifikasi), metode yang digunakan, alat dan bahan obat yang digunakan serta fasilitas pelayanan kesehatan tradisional (sarana prasarana). Dalam melakukan penilaian teknis maka Seksi Pelayanan Kesehatan Tradisional bekerjasama dengan tim penilai teknis lintas program. Jlka memenuhi syarat maka akan dibuatkan rekomendasi sedangkan jika tidak maka rekomendasi ditolak dan dilakukan pembinaan. 
b) Kunjungan berkala melalui terjun langsung ke lapangan atau tempat praktik pelayanan kesehatan tradisional empiris

Dinas Kesehatan Kabupaten Buleleng melakukan pengawasan juga berdasarkan laporan berkala puskesmas. Selain itu Dinas juga melakukan sidak secara berkala ke daerah. Jika saat dilakukan sidak dan ditemukan adanya temuan, maka temuan tersebut dievaluasi apakah termasuk pelanggaran administrasi, hukum, atau pelanggaran etik. Apabila temuan termasuk pada pelanggaran administrasi maka Dinas Kesehatan Kabupaten Buleleng akan memberikan pembinaan, namun jika termasuk pelanggaran hukum maka akan ditindaklanjuti oleh penagawasan di bidang hukum dan jika termasuk pelanggaran etik maka akan ditindaklanjuti oleh asosiasi penyehat tradisional.

c) Berdasarkan aduan masyarakat

Dalam hal terdapat aduan dari masyarakat, maka Dinas Kesehatan Kabupaten Buleleng akan melakukan verifikasi terhadap kebenaran data yang ada dengan melakukan sidak. Kemudian data tersebut dievaluasi apakah termasuk pelanggaran hukum atau etik yang selanjutnay ditindaklanjuti. Namun sampai saat ini Dinas Kesehatan Kabupaten Buleleng belum menerima ataupun mendengar adanya aduan dari masyarakat terkait dengan pelayanan kesehatan tradisional empiris yang ada di Kabupaten Buleleng.

3) Melakukan tahap akhir pengawasan

Setelah dilakukan evaluasi terhadap hasil temuan, maka akan dilanjutkan dengan melakukan tindak lanjut.

\section{d. Objek pengawasan}

Terdapat tujuh objek yang diawasi antara lain : kelengkapan administrasi, tempat pelayanan kesehatan tradisional empiris dan sarana prasarana, kualifikasi penyehat tradisional, bahan obat tradisional, iklan dan metode pelayanan serta prosedur pelayanan. Ketujuh objek tersebut antara lain :

1) Kelengkapan administrasi

Kelengkapan administrasi yang diawasi antara lain dokumen STPT, legalitas panti sehat seperti izin panti sehat berkelompok, surat keterangan magang (jika melakukan magang dengan penyehat tradisional senior), melakukan pencatatan dan pelaporan. Berdasarkan hasil penelitian didapatkan jika penyehat tradisional tidak memiliki STPT, tidak memiliki izin panti sehat berkelompok namun sudah memiliki izin usaha, tidak membuat pencacatan serta pelaporan.

2) Tempat pelayanan kesehatan tradisional empiris, saran dan prasarana

Objek lain yang diwasi meliputi papan nama hattra serta ruangan yang disediakan sesuai dengan kebutuhan tindakan dan klien. Begitu pula dengan alat dan teknlogi yang digunakan harus berdasarkan peraturan yang telah ditetapkan yakni memiliki standar keamanan bagi klien dan tidak menggunakan alat diagnostik kedokteran.

Berdasarkan hasil penelitian, didapatkan ada penyehat tradisional yang memasang papan nama hattra namun tidak mengikuti ketentuan peraturan perundangan. Jika dilihat dari sarana prasarana yang ada kurang mendukung pelaksanaan pelayanan seperti tidak memiliki ruangan yang layak untuk 
melakukan pelayanan dimana higenitas, sanitasi serta sistem penghawaan yang kurang memadai. Penyehat tradisional yang meggunakan teknik manual seperti pijat, akupresur dan refleksi menggunakan jari tangan dan menggunakan pemijat manual dari kayu. Mereka tidak menggunakan alat dan teknologi diagnostik kedokteran.

3) Kualifikasi penyehat tradisional

Pengawasan juga dilakukan terhadap kualifikasi penyehat tradisional. Dimana dalam hal ini penyehat tradisional harus memiliki sertifikat kompetensi ataupun pernah mengikuti pelatihan terkait dengan pelayanan yang diberikan. Tindakan yang dilakukan penyehat tradisional terhadap klien meliputi keterampilan berdasarkan teknik manual, teknik energi, dan teknik olah pikir serta pemberian obat tradisional atau ramuan.

Berdasarkan hasil penelitian didapatkan jika ada beberapa penyehat tradisional yang memberikan pelayanan dengan menggunakan teknik manual seperti akupresur, pijat, refleksi dimana beberapa penyehat ada yang memang memiliki sertifikat pelatihan dan sering mengikuti pelatihan, namun ada juga yang memang sudah pernah magang dan mengikuti pelatihan namun tidak mendapatkan sertifikat pelatihan. Beberapa penyehat tradisional yang menggunakan teknik olah pikir seperti spiritual dan yoga/meditasi walaupun sering mengikuti dan memberikan pelatihan serta keterampilan tersebut didapatkan dari keturunan, namun mereka tidak memiliki sertifikat kompetensi. Penyehat tradisional yang menggunakan ramuan dimana ramuan yang diracik sendiri berdasarkan ilmu yang telah diperoleh secara turun temurun dan pelatihan memang sudah memiliki sertifikat kompetensi serta sudah bergabung dengan asosiasi ramuan tradisional Indonesia. Penyehat tradisional yang menggunakan kombinasi antara teknik manual dan ramuan seperti SPA, terapisnya juga sudah memiliki sertifikat kompetensi dan sering mengikuti pelatihan.

4) Bahan obat tradisional

Obat tradisional yang diberikan harus sesuai dengan peraturan perundangundangan yang berlaku. Adapun obat tradisional yang diberikan seperti obat tradisional yang berasal dari hasil racikan sendiri seperti jamu yang dibuat segar, ramuan simplisia kering ataupun ramuan obat luar. Obat tradisional yang diberikan antara lain obat tradisional yang sudah memiliki izin edar selain itu jika merupakan hasil racikan sendiri maka obat tersebut harus sesuai dengan peraturan perundang-undangan yang berlaku. Hasil penelitian menunjukkan jika penyehat tradisional yang menggunakan ramuan sudah berdasarkan peraturan perundang-undangan dan buku panduan pengobatan ramuan tradisional Indonesia yang dimiliki serta berdasarkan pelatihan yang memang sudah sering diikuti.

5) Metode pelayanan

Metode pelayanan yang dilakukan juga harus sesuai dengan konsep dan ciri khs pelayanan kesehatan tradisional empiris. Penyehat tradisional dilarang unuk melakukan tindakan invasiv. Adapun metode yang digunakan meliputi metode ramuan, keterampilan ataupun perpaduan antara ramuan dan keterampilan. Metode pelayanan terkait dengan teknik melakukan pelayanan tradisional 
empiris wajib untuk diawasi. Dimana dalam memberikan pelayanan kepada klien, terapis SPA, akupresur, dukun bayi yang melakukan pijat pada bayi dan refleksi harus mengetahui titik-titik saraf klien sehingga dapat memberikan pelayanan sesuai dengan keluhannya. Begitu juga dengan metode patah tulang, aka ia harus mengetahui rangka tubuh manusia dan anatomi sehingga dapat melakukan pelayanan secara tepat. Metode ramuan atau obat tradisional juga demikian, ia harus mengetahui tanaman herbal atau bahan lain yang memang sesuai untuk dibuat ramuan atau obat tradisional.Berdasarkan hasil penelitian didapatkan jika penyehat tradisional lebih banyak menggunakan metode keterampilan dan mereka juga tidak melakukan tindakan yang membahayakan klien seperti tindakan invasif atau melukai klien.

6) Iklan

Iklan dari penyelenggara pelayanan kesehatan tradisional juga wajib untuk diawasi. Menginat hal ini akan memiliki dampak yang nantinya akan merugikan masyarakt apabila iklan tersebut tidak benar dan tidak dapat dipertanggungjawabkan. Apalagi dalam pelayanan kesehatan tradisional empiris, dimana penyehat tradisional tidak diperbolehkan untuk melakukan publikasi atau iklan terkait pengobatan yang digunakannya. Berdasarkan hasil penelitian dilihat jika penyehat tradisional rata-rata tidak melakukan publikasi atau iklan.

7) Prosedur pelayanan

Adapun hal yang diawasi selanjutnya adalah prosedur pelayanan yang diberikan oleh penyehat tradisional. Dalam memberikan pelayanan kepada klien, penyehat tradisional wajib untuk memberikan informasi atau penjelasan terkait dengan pelayanan yang akan diberikan serta wajib untuk mengkaji kembali kondisi klien apakah tindakan yang diberikan sesuai dengan kebutuhan atau tidak. Di samping itu penyehat tradisional juga wajib untuk memberikan jaminan rahasia kepada klien terkait kondisinya. Hal ini diperlukan sebagai upaya memenuhi hak klien. Hal tersebut sesuai dengan Peraturan Menteri Kesehatan Nomor 61 Tahun 2016 Tentang Pelayanan Kesehatan Tradisional Empiris.

Melihat uraian tersebut, jika ditinjau berdasarkan hasil penelitian maka banayk penyehat tradisional yang melakukan pelanggaran. Hal ini menunjukkan jiak ketujuh objek tersebut belum sepenuhnya diawasi secara optimal. Demi memberikan perlindungan terhadap hak sehat masyarakat, maka ketujuh objek tersebut wajib untuk diawasi oleh Dinas Kesehatan Kabupaten Buleleng.

\section{e. Tindak lanjut pengawasan}

Tindak lanjut dari temuan terhadap pengawasan yang dilakukan Dinas Kesehatan Kabupaten Buleleng antara lain memberikan laporan kepada Dinas Kesehatan Provinsi sebagai bagian dari kewajiban administrasi, memberikan pembinaan terhadap pemegang program puskesmas dan penyelenggara pelayanan kesehatan tradisional, serta memberikan tindak lanjut terhadap pelanggaran baik itu pelanggaran etik, administrasi ataupun hukum. Dalam hal ini, berdasarkan hasil penelitian, Seksi Pelayanan Kesehatan Tradisional Dinas Kesehatan Kabupaten Buleleng memberikan pembinaan kepada penyehat tradisional terkait peraturan dan syarat-syarat yang harus dipenuhi. Adapun penerapan sanksi belum 
diberlakukan. Hal tersebut mengakibatkan belum sepenuhnya hak sehat masyarakat dilindungi.

\section{Faktor-Faktor yang mempengaruhi Pengawasan}

\section{a. Faktor Yuridis}

Faktor yuridis yang mempengaruhi seperti belum ada Peraturan Daerah Provinsi ataupun Kabupaten terkait penyelenggaraan pelayanan kesehatan tradisional empiris dan dalam PMK Pelayanan Kesehatan Tradisional Empiris belum dijelaskan secara lengkap mengenai pasal terkait penerapan sanksi administrasi terhadap penyehat tradisional yang belum memiliki STPT dengan waktu yang diberikan untuk pengurusan STPT namun dalam lampiran penjelasan PMK hal tersebut sudah dicantumkan. Hal ini dapat menghambat pelaksanaan dari pengawasan sehingga pelaksanaan pengawasan tidak dapat berjalan secara optimal.

\section{b. Faktor Sosial}

Dilihat dari faktor sosial, pemahaman masyarakat masih belum baik terhadap pelayanan kesehatan tradisional atau pengobatan tradisional tersebut. Informasi yang didapatkan oleh masyarakat tentang pelayanan kesehatan tradisional juga masih belum jelas, dimana saat ini banyak beredar informasi terkait pengobatan tradisional yang berlebihan dan cenderung menjerumuskan masyarakat. Kepedulian masyarakat terhadap pelayanan kesehatan tradisional atau pengobatan tradisional juga masih kurang dimana masyarakat kurang peduli dan tidak melaporkan jika ada kejadian yang merugikan masyarakat. Hal tersebut dapat menghambat pelaksanaan dari kegiatan pengawasan dan pengawasan tidak berjalan dengan efektif.

\section{c. Faktor teknis}

Terkait faktor teknis, Dinas Kesehatan Kabupaten belum memiliki SOP (Standar Operasional Prosedur) dalam pengawasan dan pembinaan yang dilakukan terhadap penyelenggara pelayanan kesehatan tradisional empiris dan hal ini dapat menghambat pelaksanaan pengawasan pelayanan kesehatan tradisional empiris. Koordinasi antar instansi juga belum maksismal. Selain itu kurangnya sumber daya manusia yang memang ahli di bidang pelayanan kesehatan tradisional empiris, sumber dana, serta sarana prasarana pendukung yang terbatas dapat juga menghambat kegiatan pengawasan yang dilakukan.

\section{PENUTUP}

\section{SIMPULAN}

Adapun simpulan yang dapat diambil dari penelitian ini antara lain :

\section{a. Pengaturan Penyelenggaraan Pelayanan Kesehatan Tradisional Empiris}

1) Dasar hukum Pelayanan Kesehatan Tradisional Empiris meliputi berbagai ketentuan yaitu Undang-Undang Dasar Negara Republik Indonesia tahun 1945, Undang-Undang Nomor 8 Tahun 1999 tentang Perlindungan Konsumen, Undang-Undang Nomor 32 Tentang Penyiaran, Undang-Undang Nomor 10 Tahun 2009 Tentang Kepariwisataan, Undang-Undang Nomor 36 Tahun 2009 Tentang Kesehatan, Undang-Undang Nomor 23 Tahun 2014 Tentang Pemerintahan Daerah, Peraturan Pemerintah Nomor 103 Tahun 2014 Tentang Pelayanan 
Kesehatan Tradisional serta Peraturan Presiden Nomor 72 Tahun 2012 Tentang Sistem Kesehatan Nasional.

2) Masing-masing ketentuan pada intinya mewajibkan pemerintah untuk bertangung jawab dan menjamin setiap orang agar mendapatkan hak untuk hidup sehat dimana pengembangan pelayanan kesehatan tradisional merupakan bagian dari pengembangan budaya. Dengan demikian Pemerintah dalam hal ini dinas kesehatan kabupaten/kota wajib untuk melaksanakan pembinaan, pengawasan, dan tindak lanjut terkait sanksi sebagai bentuk perlindungan hak sehat bagi masyarakat.

3) Bentuk Pengaturan Pelayanan Kesehatan Tradisional Empiris secara umum diatur dalam PMK Pelayanan Kesehatan Tradisional Empiris Tahun 2016. Dalam pengaturan ini diatur 11 hal penyelenggaraan pelayanan kesehatan tradisional empiris.

4) Selain PMK Pelayanan Kesehatan Tradisional, hal tersebut diatur pula pada Peraturan Menteri Kesehatan lainnya seperti Peraturan Menteri Kesehatan Nomor 1787 Tahun 2010 Tentang Iklan dan Publikasi, Peraturan Menteri Kesehatan Nomor 90 Tahun 2013 tentang Sentra Pengembangan dan Penerapan Pengobatan Tradisional (SP3T), Peraturan Menteri Kesehatan Nomor 8 Tahun 2014 Tentang Pelayanan Kesehatan SPA, Peraturan Menteri Kesehatan Republik Indonesia Nomor 6 tahun 2016 tentang Formularium Obat Herbal Asli Indonesia, serta Peraturan Menteri Kesehatan Republik Indonesia Nomor 9 tahun 2016 tentang Upaya Pengembangan Kesehatan Tradisional Melalui Asuhan Mandiri Pemanfaatan Taman Obat Keluarga Dan Keterampilan. Selanjutnya diatur pula pada Peraturan Menteri Pariwisata Nomor 18 Tahun 2016 Tentang Pendaftaran Usaha Pariwisata serta Peraturan KPI Nomor 02/P/KPI/03/2012 Tentang Standar Program Siaran.

5) Tujuan Pengaturan penyelenggaraan pelayanan kesehatan adalah untuk melaksanakan amanat peraturan perundang-undangan, sebagai salah satu bentuk pengawasan preventif yang dilakukan Pemerintah Daerah, sebagai bentuk perlindungan hak sehat masyarakat dengan memberikan jaminan kepada masyarakat guna mendapatkan pelayanan yang bermutu, dan sebagai pedoman dalam menyelenggarakan pelayanan kesehatan tradisional empiris

b. Pelaksanaan Pengawasan Dinas Kesehatan Kabupaten Buleleng Terhadap Penyelenggaraan Pelayanan Kesehatan Tradisional Empiris dan Perlindungan Hak atas Kesehatan Bagi Masyarakat

1) Lembaga yang sepenuhnya melakukan pengawasan di tingkat kabupaten khususnya dalam lingkup Kabupaten Buleleng adalah Dinas Kesehatan Kabupaten Buleleng. Agar pelaksanaan pengawasan dapat berjalan efektif maka dalam hal pelaksanaan pengawasan dinas kesehatan dapat berkoordinasi dengan instansi terkait yang memiliki kewenangan berbeda terhadap penyelenggaraan pelayanan kesehatan tradisional empiris seperti Dinas Pariwisata, Lembaga Penyiaran dan Asosiasi Penyehat Tradisional.

2) Terkait kewenangan pengawasan maka Dinas Kesehatan melakukan pengawasan terkait hal teknis seperti kelengkapan administrasi, tempat 
pelayanan kesehatan tradisional empiris dan sarana prasarana, kualifikasi penyehat tradisional, bahan obat tradisional, metode pelayanan serta prosedur pelayanan. Dinas Pariwisata melakukan pengawasan terkait kesesuaian usaha yang dilakukan dengan TDUP yang dimiliki. Lembaga penyiaran difungsikan untuk memilah penyiaran iklan dari pelayanan kesehatan tradisional. Asosiasi penyehat tradisional melakukan pengawasan terkait keanggotaan dari asosiasinya

3) Pengawasan dilakukan oleh Dinas Kesehatan Kabupaten Buleleng dalam hal ini seksi pelayanan kesehatan tradisional yang melakukan kewajiban tersebut.

4) Dinas Kesehatan Kabupaten lebih banyak melakukan pengawasan represif dibandingkan dengan pengawasan preventif.

5) Dinas Kesehatan Kabupaten Buleleng juga bertindak sebagai pelapor atau dengan kata lain melakukan kerjasama dengan penyidik atau lembaga yang berwenang jika ditemukan pelanggaran hukum.

6) Mekanisme pengawasan yang dilakukan ada tiga tahapan

7) Terdapat tujuh objek yang diawasi namun belum diawasi secara optimal oleh Dinas Kesehatan Kabupaten Buleleng sehingga belum dapat melindungi hak sehat masyarakat

8) Tindak lanjut yang dilakukan terhadap pelanggaran yang ada adalah melakukan pembinaan. Sampai saat ini sanksi belum dapat diterapkan secara tegas

9) Pengawasan yang dilakukan oleh Dinas Kesehatan Kabupaten Buleleng sudah sesuai dengan PMK Pelayanan Kesehatan Tradisional Empiris namun pelaksanaannya belum optimal. Pelaksanaan yang belum optimal ini secara tidak langsung mengakibatkan hak atas kesehatan bagi masyarakat belum dapat dilindungi.

\section{c. Faktor-Faktor yang mempengaruhi Pelaksanaan Pengawasan}

Terkait dengan faktor yang mempengaruhi pelaksanaan pengawasan, maka ketiga faktor yakni faktor yuridis, sosial dan teknis sama-sama saling mempengaruhi.

1) Faktor yuridis yang mempengaruhi seperti belum ada Peraturan Daerah Provinsi ataupun Kabupaten terkait penyelenggaraan pelayanan kesehatan tradisional empiris dan belum dijelaskan secara lengkap mengenai pasal terkait penerapan sanksi administrasi dapat menghambat pelaksanaan pengawasan

2) Dilihat dari faktor sosial, pemahaman masyarakat masih belum baik terhadap pelayanan kesehatan tradisional, informasi yang didapat juga masih belum jelas dan terkadang berlebihan serta menjerumuskan. Masyarakat juga kurang peduli dan tidak melaporkan jika ada kejadian yang merugikan masyarakat. Hal ini dapat menghambat pelaksanan pengawasan yang dilakukan

3) Terkait faktor teknis, belum adanya SOP juga menghambat pelaksanaan pengawasan. Selain itu koordinasi antar instansi terkait yang belum optimal, terbatasnya SDM yang memang ahli di bidang kesehatan tradisional serta terbatasnya dana dan sarana prasaran pendukung juga dapat menghambat pelaksanaan dari pengawasan. 


\section{SARAN}

a. Pemerintah dalam menjalankan kewajiban dan tanggung jawabnya terhadap pelaksanaan pelayanan kesehatan tradisional seharusnya diperlukan ketentuan hukum di tingkat provinsi atau kabupaten/kota, baik itu ketentuan hukum yang mengatur secara umum ataupun secara khusus. Untuk itu Peraturan Daerah atau Peraturan Bupati segera dibuat terkait dengan pelayanan kesehatan tradisional empiris yang ada di daerah.

b. Pemerintah dalam menunjang pelaksanaan pengawasan dan perlindungan terhadap hak sehat masyarakat wajib untuk menerapkan sanksi secara tegas seperti pemberian denda kepada pihak yang melanggar.

c. Pemerintah dalam melaksanakan pengawasan khususnya dalam kaitannya dengan obat tradisional sebaiknya mengacu pada Undang-Undang Perlindungan Konsumen Nomor 8 Tahun 1999.

d. Pemerintah untuk melakukan pengawasan pelayanan kesehatan tradisional ini membentuk tim terpadu yang melibatkan dinas pariwisata, lembaga penyiaran, asosisasi penyehat tradisional dan dinas kesehatan. Selain itu juga dibuat peraturFFan mengenai unsur-unsur pengawasan terpadu.

e. Pelayanan kesehatan tradisional empiris yang memang mengacu pada budaya nasional merupakan aset pariwisata dimana memiliki potensi menjadi wisata kesehatan dan Pemerintah dapat menPgembangkannya menjadi wisata kesehatan.

f. Pemerintah dalam menunjang pelaksanaan pengawasan sebaiknya mendukung dalam hal penyediaan dana, sumber daya manusia serta sarana prasarana sehingga Dinas Kesehatan Kabupaten/Kota dapat melakukan pengawasan secara maksimal.

g. Pemerintah dalam menunjang pelaksanaan penyelenggaraan pelayanan kesehatan tradisional empiris diharapkan untuk mengembangkan Lembaga Sertifikat Kompetensi di daerah sehingga penyehat tradisional yang ada dapat mengurus sertifikat kompetensinya.

h. Diperlukan acuan terkait operasional dari tindakan pengawasan. Jadi seharusnya dibuat SOP pelaksanaan pengawasan.

i. Pemerintah sebaiknya lebih melakukan pengawasan preventif sehingga pelayanan kesehatan tradisional yang tidak bertanggung jawab tidak bisa melakukan pelayanan kepada masyarakat.

j. Pemerintah dalam hal ini Dinas Kesehatan Kabupaten Buleleng sebaiknya melakukan pengawasan terhadap ketujuh objek pengawasan (kelengkapan administrasi, tempat penyelenggaraan dan sarana prasarana, kualifikasi penyehat tradisional, metode pelayanan, bahan obat tradisional, iklan serta prosedur pelayanan).

k. Pemerintah dalam melaksanakan proses pembinaan wajib melakukan sosialisasi terkait pelayanan kesehatan tradisional baik kepada masyarakat sebagai penyelenggara ataupun sebagai pengguna. Dimana dalam melakukan sosialisasi kepada masyarakat, pemerintah lebih menekankan pada resiko yang terjadi apabila memang penyehat tradisional tersebut tidak memiliki keahlian sesuai dengan 
pelayanan yang diberikan. Begitupun dengan penyelenggara untuk lebih meningkatkan kompetensi yang dimilki dan wajib untuk memiliki sertifikat kompetensi.

I. Penyelenggara pelayanan kesehatan tradisional empiris wajib untuk mematuhi peraturan terkait pelayanan kesehatan tradisional empiris.

m.Masyarakat diharapkan lebih selektif dalam memilih dan menggunakan pelayanan kesehatan traditional empiris serta segera melaporkan kepada puskesmas atau Dinas Kesehatan Kabupaten atau kepada lembaga yang berwenang jika mengalami kerugian atau tidak mendapatkan pelayanan yang baik.

\section{DAFTAR PUSTAKA}

Badan Penelitian dan Pengembangan Kesehatan, 2013, Riset Kesehatan Dasar. Jakarta : Kementrian Kesehatan Republik Indonesia

Satjipto Rahardjo, 2000, Ilmu Hukum, Bandung : Citra Aditya Bakti

Sumardjo. 2001. Menyikapi Fungsi Pengawasan dan Temuan. Jakarta : BP Panca Usaha

Undang-Undang Dasar Negara Republik Indonesia Tahun 1945

Undang-Undang Negara Republik Indonesia Nomor 8 Tahun 1999 Tentang Perlindungan Konsumen

Undang-Undang Republik Indonesia Nomor 32 Tahun 2002 Tentang Penyiaran

Undang-Undang Republik Indonesia Nomor 36 Tahun 2009 tentang Kesehatan

Undang-Undang Republik Indonesia Nomor 10 Tahun 2009 Tentang Kepariwisataan

Undang-Undang Republik Indonesia Nomor 23 Tahun 2014 tentang Pemerintahan Daerah

Peraturan Pemerintah Nomor 103 tahun 2014 tentang Pelayanan Kesehatan Tradisional

Peraturan Menteri Kesehatan Republik Indonesia Nomor 1787 Tahun 2010 Tentang Iklan Dan Publikasi

Peraturan Menteri Kesehatan Republik Indonesia Nomor 90 Tahun 2013 Tentang Sentra Pengembangan Dan Penerapan Pengobatan Tradisional (SP3T)

Peraturan Menteri Kesehatan Republik Indonesia Nomor 8 tahun 2014 Tentang Pelayanan Kesehatan SPA

Peraturan Menteri Kesehatan Republik Indonesia Nomor 6 Tahun 2016 Tentang Formularium Obat Herbal Asli Indonesia (FOHAI)

Peraturan Menteri Kesehatan Republik Indonesia Nomor 9 Tahun 2016 Tentang Upaya Pengembangan Kesehatan Tradisional Melalui Asuhan Mandiri Pemanfaatn Tanaman Obat Keluarga Dan Keterampilan

Peraturan Menteri Kesehatan Republik Indonesia Nomor 61 Tahun 2016 Tentang Pelayanan Kesehatan Tradisional Empiris 
Peraturan Menteri Pariwisata Republik Indonesia Nomor 18 Tahun 2016 Tentang Pendaftaran Usaha Pariwisata

Peraturan Presiden Republik Indonesia Nomor 72 tahun 2012 tentang Sistem Kesehatan Nasional

Peraturan Komisi Penyiaran Indonesia Nomor 02/P/KPI/03/2012 Tentang Standar Program Siaran

Internet, 19 Juli 2016, Waspada! Ribuan Penyehat Tradisional Tak Kantongi ljin Praktik, http://www.radarbali.jawapos.com/read/2016/07/19/4184/waspada-ribuanpenyehat-tradisional-tak-kantongi-izin-praktik/1

Internet, 19 Juli 2016, 3056 Tempat Praktik Balian di Bali Tak Berizin, Tinggal di Pedesaan dan Kaki Gunung, http://www.bali.tribunnews.com/2016/07/19/3056-tempatpraktik-balian-di-bali-tak-berizin-tinggal-di-pedesaan-dan-kaki-gunung/page=all 